POSSIBLE INTERREIATTONSIITP OF $\Lambda \mathrm{CAN}$ 'THOMA ADENOIDES CYSTICUM (MUITIPLE BENIGN CYSTIC EPITHELIOMA)

AND SYRINGOCYSTADENOMA (IYMMPIIANGIOMA TUBEIROSUM MULTIPLEX)

RICIJARD I. SUT'TON, M.D.

Professor of Dermatolegy, Tinfversfly of Kinnsus AN1)

CIIARLES C. DENNIE, A.J3.

Student Assistant In Inthologr, Univelisity of Kansas JANSAS CITY, MO.

Unua ${ }^{2}$ preters, on anatomic grounds, to group all tumors derived from the prickle-sell layer under the precise and at the same time comprehensive heading of "lanthomata. This term, first suggested by Auspit\%" scrves admirably when it is desired to draw a sharp line of demarcation between these. growths and those originating from other cutancous structures. Unfortunately, in some instances the point of origin is a matter of doubt, and particularly is this true in many of the lesions that have been reported as examples of multiple benign cystic epithelioma. 'Typi(a! instances of this affection, which wns first described almost simultaneously by Brook ${ }^{3}$ and by Fordyce, ${ }^{4}$ in 1892 , are easily irlentified listologically, but some of thic variant and mixed forms are cxtremely difticult to classify.

The tumor of this type which lans given rise to the greatest amount of controversy is one first reported by Biesiadecki and Kaposi," and named by them "Iymphangiona tuberosum multiplex." While it is generally conceded that these authors were mistaken regarding the origin of the growths, the designation bestowed by them lins been allowed to stand, partly on account of priority, but principally because of the inclefiniteness of our knowledge conecrning the origin of the epithelinl processes of which the tumors are largely composed. The soures from which the epithelium can be derived are limited - it must enme dirently from the prickle layer of the skin or hair follicle. from the enil or duet of the sweat apparatus, or from the endothelinm of the bloot-ressels, or, theoreticalsy. it may develop from misplaced ombryonic rudiments of one or more of these structures (a so-ealled Colmheim's rest, or, according to Ribbert's theory of mechanic isolafion. from cells that aceident las semoved from the influence of normal cell associntion).

An idea of the lack of unanimity of opinion amoner the various investigators may be gained by a very casual survey of the literature. Almost every observer has soen fit to renane the affection, giving it a title that corresponded with his conception of the origin of the epithelial accumnlations. 'The resulting cognomens vary from the "cellulome épithéljal éruptif" of Quinquaud.? and

1. Ifnnu: Histomathology of the Insenses of the skin, J'runt. by Wulker, Mncmllan Compony, Now York, 1800, p. T84.

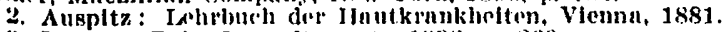

3. Rrooke: Brit. Jour. Jermut. 189)2, p. 2(3i).

4. Fordyce: Jour. Cutin. IVis., 1892, p. 450 .

5. Blesiadeckl: Unterkuchungen aus dem pathol.-snat. Instituto Im lienknu, 187\%, p. 2.

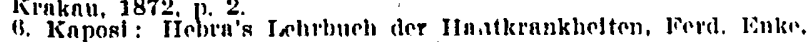
slutigart, 1870 . it, 28:.

7. Quinquaud: 'Tr. Internat. Cong. Jernat., l'arls, 1889, p. 412. the "navi epritheliaux kystiques" of Besnier to the "Iammangendothelioma cutis papmlosum" of Waldhcim" and the "navid cyst-epitheliomitosi disseminiti" of Gassmamn. ${ }^{10}$ Recently we have hat an onnortunity to make a comparative study of multiple benign cystic epithelioma and lymplanngioma tuberosum multiplex, and the findings are of interest as serving to emphasize the neressity of separately classifying these two varieties of non-malignant, cystic, cutancons neoplasms.

\section{C.ISE RiERT'T}

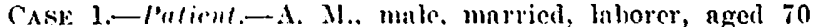
years, was first admittel to Dr. llalter Sutton's service (sur.

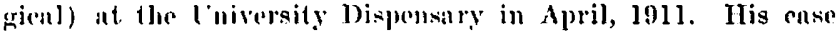
was there diagnosed as one of multiple benign cystic epithelioms by Prof. W. K. Trimble. to whom some of the biopsied materint had been sent for mieroseopic examination. When the elinie for skin diseases Was opened in Oetober, Dr. Sutton kindly referred the patient to us for further observation and trentmont.

lamily Misfory.-The cutuneous history of the family is negative. The gatient has bern twice murried, and has seven children. nged from 12 to 40 yents, nll of whom are living and in good health. So far as the father knows, none of them has ever been troubled with a skin disease of any kind.

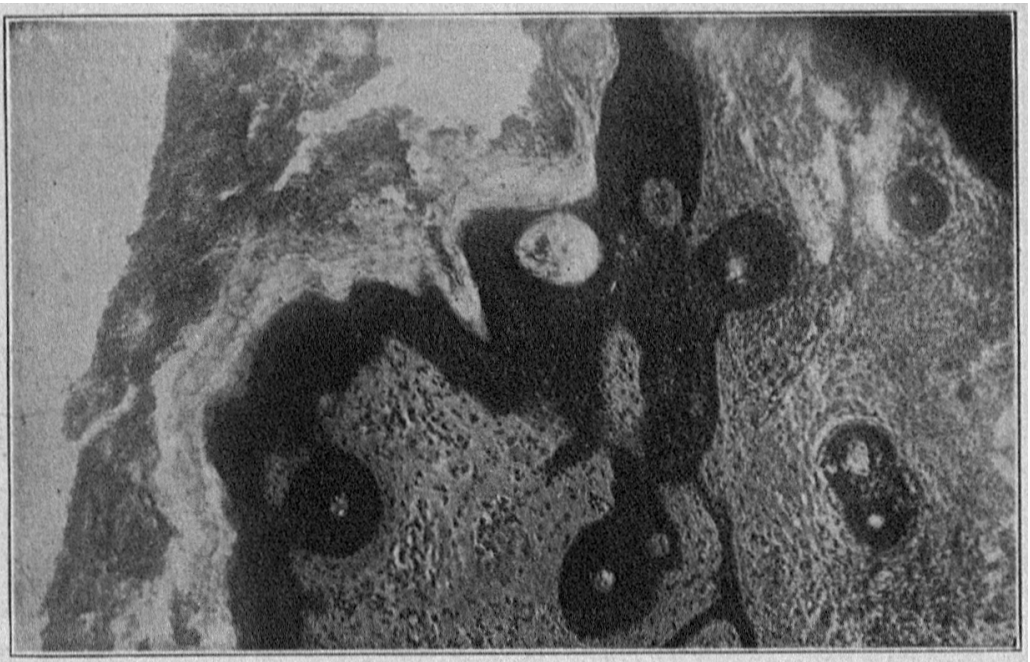

10. 1.-Acnnthomn ndenoldes cysticum, showing epithelinl strands extending nward fiom priclicecell lnyer with nimerous eysis. (Spencer $1 / 6$ obj. No

Persemal History.-The putient is a native of Ohio, and " resident of Missouri. His general health has always been fairly gool. At virions times, however, he has suffered from rhoumntism, crzomm, seborrhoic dermntitis, and urticaria.

Present Mllness.--The smnll tumors on the patient's forc. hend, neck, and bnek have beon present ever since ho can recollect. ()ne of the larger glowths, on the left side of the neek, berame hard nmil julumated in .Jume, 1911, nnd ulcerated $n$ few weeks lnter. (linically, n typienl rodent uleer resulted, and the (antire lesion was exeised by Dr. Walter Sutton in August, 1911 .

Examination.-Jhe pationt was a well-mourished man, and appeared to be much youmger than lis nge would indichte. 'The Wusserman sero-renction was negntive, and there was no response to tuloreulin. Iliese whs some senile atrophy of the skin, purticulurly on the bucks of the hands. The hair was thin, and there was considuruble brunuy senliness (seborylueic) on the senlp nud fuce. There were a few pigmented nevi on tho rhest and lack. The skin of the trunk was reddened, and there was a docidod tembeney to dermographism. Irregulurly senttered over the senlp, tomples, neck, and chest were a num.

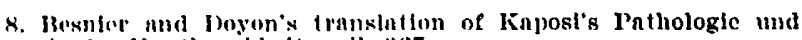

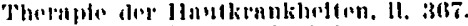

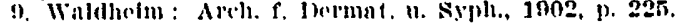

10. (inssmumn: Arch. f. Bermnt, u. Sybll., J001, p. 177. 
ber, seven in all, of the smull, pink, nodular tumors chatace-

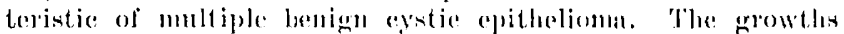
varied in size from a grain of whent to a split pou, and did not disajperar on pressure.

Mistopathologyg.-Fiwo of the lesions were excised for bahoratory purpeses, one from the left senpulat region, the othere from the right temple. The first piece of tiselle was frozent

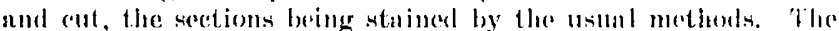
second was fixed in formaldelyed solution, and monuted in puration. The findingersere practiendly identical in the two tumors. 'The corium was somewhat disorganized, considerable

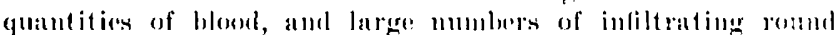
cells beingr present. No laij follicless, or sebaceons or aril glands were foumel in eitles of the specinuens. Wxtonding

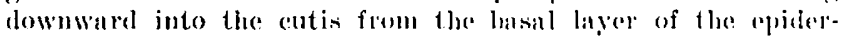
mis were numerous long, shemder elutins of epitholium, two or three cels in width, whicls forminated in buld-like eyts, filled with colloid substatase and corfinous material. Soveral

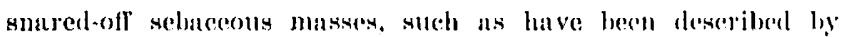

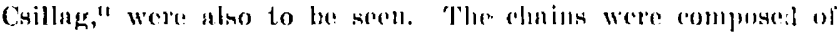

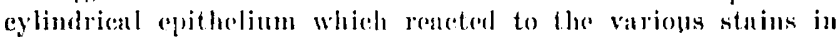
a manner exactly similar to the apparently normal eells in the overlying epidermis. No frece tracts were to be found. the ontermost eovering of the club-slated projoctions consisted nlways of a layer of cylinclrionl epithelium-in no

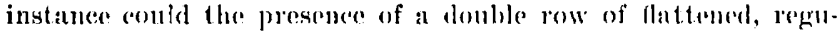
larly arranged eells be demonstrated-and an immer zoue of

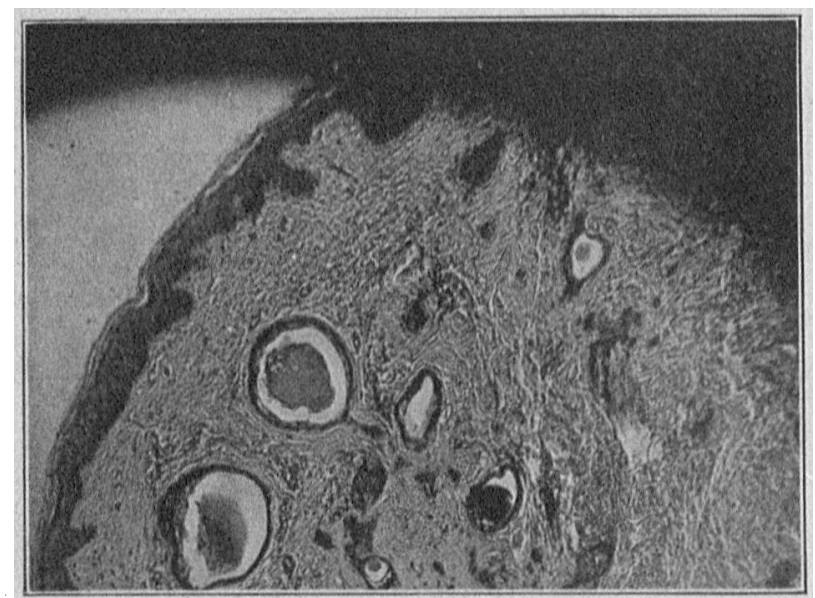

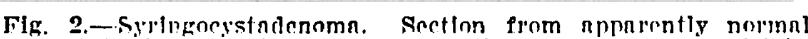

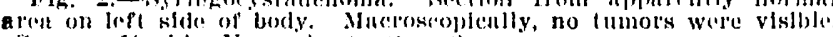

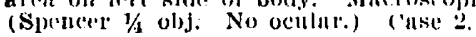

imperfectly stuined, roumled ('pithelial eells, encireling a central mass of doluris.

('ask: 2.-l'aticut-M. D)., fomale, marriod, houscwife, nged 39, was a putient of J)rs. J. Phillip Knnoky and Richald $\mathrm{l}$. Sutton, and we tre indeletel to Dr. Kanoky for permission to aceord the history and the microsecopie findings.

Family lisfory. - Sio far ne the pationt is able to discover, no other member of the fumily has ever had a similar disorder. She is the mother of three children, nged 16,9 and 3 years respectively, nll of whom are living and woll.

I'ersomal History.-The putient is n mutive of Missouri, and a resident of kinnsas (ity, Her general health has never beron good, although she hats experiencerl no rovere jllnesses. She never feels well duringe the excensively hot wenther, and uscribres her weikness and disenmfort to her indbility to perspire freely, a peculiarity to which she lan been subject ever since she orn rememher.

Present Jllness.- lor many yeats thore lave heen proserit numerous small, whitish or pinkish jalpules, varying an sizo from a hemp-sead to the linlf of a soup-herin, on hoth sidies of the patient's forelsead, and on the right side of her chest, near the anterior axillary border. The little tumors lave never given rise to subjective symptoms, and slight nttention has been paid to them.

11. Cofllag: Arch. e. Inemat. 11. Syph., 1000, p. 16i3.
Examination. - The patient is a bunette, with brown eyes and hair. Iler skin is soft, smonth and flexible. lhore nre a fow acue lesions on the loft sille of the chin, and a slight

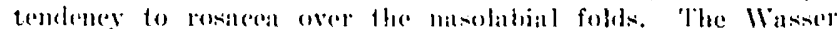
mann test is mogative, but there is a slight reacedion to tuber

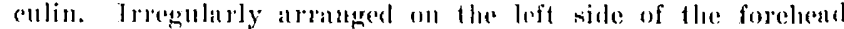
ale alosut twenty small, soft. llattencel. pinkish-white, smoothtopperl papules, somewhat larerer than the hemel of an ordiums

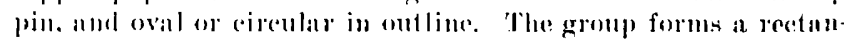

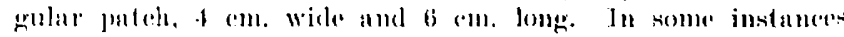
the losions have apparently entesend, the resulting tumor boine irregulaty fusiform in shaje. Tlume is a similar but smallare collection of lesions over the rieght temples.

(B) the right side of the chust, near the muterior border af the axilha, is a thitel group of the tumoss, their thrangement

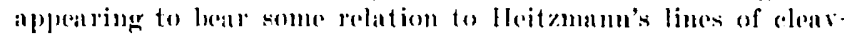
"age. 'The individanl lesions in this collection are more sharply ontlined, and the tops are more pointed than those on the fore hend. Following the ndministration of pilosmpin hydro

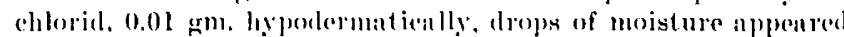
on the tops of some lut not all ai the lesions. At this time, while the pateint. was perppiring puite freoly, the tumors were pereeptibly increased in size. nud distinctly more prominent than before the dring was given.

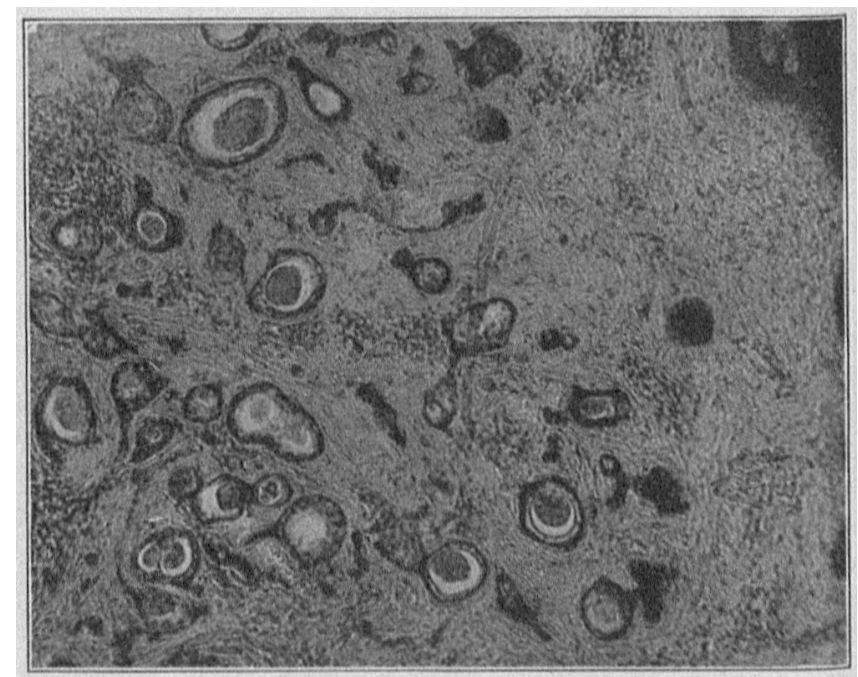

Fig. 3.-Syrtngocystndonoma, showing epithellnl stinnds" and

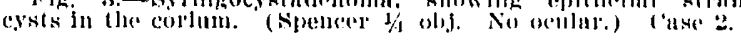

Misfopatholog!y.-At various times, eleven of the growthe. fwe from the forelend and nime from the nxillit. together with two pieces of maceseopieally mormal skin from the siales of the trunk, wore exeised for mieroseopice study. The muterinl was lixed in aleohol, formalin. or tonker's solntion. Two of the nodules were sectioned in a freveing mierotome, mol stuined with senrlet $R$ and Sudm III, alum-hemntoxylin being used as a muclenr situin. 'Tle remuinder of the material was mounted in colloidin or in purnlim, and ent at varions mugles (perpendioularly to, diagonally to, and purallel with, the sarface), and the sections afterward stained with the usual dyes. li all, nbout aleven hundred sections were exnmined.

The puthologic changes in tho epidernis were nlmost idontionl with those seenl in ('harles .J. White's: cuse-all unclunged stratum corneum. o thinned granulur layer alnost devoid of granules, and a rete having a regularly arrunged busul layer but composed of swollen, edemutoms colls, the muclei of which were large mul vesienlar, and separnted from the cneompussing eytoplasm by a comsideruble space. In the mujurity of the specimens, the papillas were flattened or entirely absent. 'There was some cellular infiltrntion in the upper corimm, but the blood-vesseds, which were considerably lessened in number, exhibited no inflammatory changes, nuid the capillary andothelium appouded normal in every way. 
The elastic tissuc was somewhat reduced in anount, nlthough the distribution of the fibers was hut litte altered and the elastic network completely encireled the eysts. ne in the cases reported by Dohi.'3 Gaissmum and Stockmann." Hair follieles and scluenems glands were found in ath of the nodules. Joth tho folliches and tho appended gramelular olements appented to be mormal. In those instances in which a complete longituclimal section of a hinif follicle was sectured, no buclding or other nhuormal condition wins to be found. Ocensiomally, one of the longe, way strunds of epithelial cells, 1. be described later, was foumel in very close proximity to it pilo-sebaceous appendage, hut coreful senreds through the serial sedions nways showed the extremities to be free, and not eomected with the follicle in any way. In ndelition, the renetion of the component parts of the two structures to the various aniline dyes was entirely different, and invariably served as a trustwortly method of identifiention.

The coil-eglands were well developed, and exhibited no patho. logie eloanges. In several instances the sluets could be traced entirely to the surface of the skin. There was no evidence of dilutation, or of eystic denencration in either coil or duct, and no iudiention of budiling or of other alonornal cell proliferation.

There was some eollagenous degeneration of the connective tissue stromn, but the change was not markel.

Senttered through the ent is, from iust below the basnl hyer of the epidernis down to the stratum of subentaneous fit, were large numbers of rouml or ovil musses of epithelium, and epithelial-lines tubules. Many of these cell collections possessed a stem-like apperndage of epithelinl eelis, two cells in width, which frequently commected two or more of the glanduInr masses. In muny instanees these epithelial tracts were found extending in various directions through the corium. 'I he nuclei of the colls were large, nud stained much more decply than those in the epidermis.

In several of the maernseopically normul sections from hoth sides of the trunk similur stranils of epithelinl cells were found, and in one spocimen soveral budding processes and a few eysts were present. It would have been interesting to study sections of skin from parts of the body that are not so ricli in coil glands as the nxilles. but further material was refused.

Case 1 is a classic example of multiple benign cystic epithelioma as origrinally described by Brooke and by Fordyce.

('.J. White, ${ }^{10}$ Tariseh ${ }^{10}$ and Stelwagon ${ }^{17}$ have reported similar coses in which the tumors underwent degenerative changes and exhibiterl evidenee of mulignaney. In this instanec, the somewhat umusual sequel might be partially explained by the concomitant seborrheic dermatitis, which had been present for many years.

In Case 2, we have a typical representative of the Jac(guet-Inurier group. In general there has been sueh a remarkable uniformity in the reported alses referred to this group that it is excedingly improbulsle that, as claimed by Möler, ${ }^{18}$ sone are of endothelinl and others of epitholial origin. While it is true that netual conneotion of the epitholial strands and cysts with preexisting swent-glands has boen missed by the majority of investigators, there are now several woll authenticated instances in whicl: such eommection lus been recognized. ${ }^{1 \text { th }}$

Thartzellen, has reported a wique neoplasm which

13. Dolis: Aroh, f. Mermat, u. Syph., 1907, p. 63,

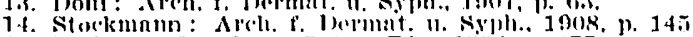

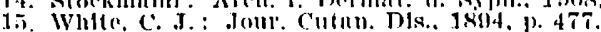

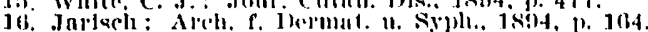

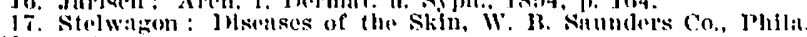
1911. 1. 6:14.

Areds. f. Dirlunt u. Syph. 1002, p. 5i.

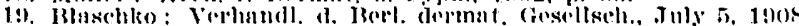

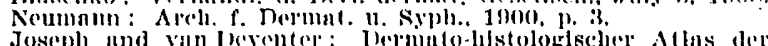

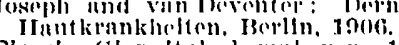

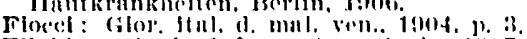

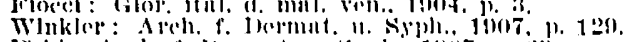

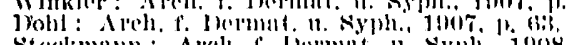

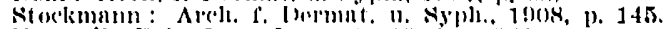

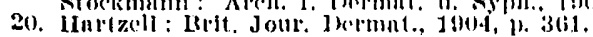

resembled in some respects both lonign erstic epitlelioma and lymphangioma tuberosm multiplex. Frequently lomer, slemelex, epithelial branches were found extending from the sides of the follicles (as in the "tricoepithelioma papillosm multiplex" of lariseh" ${ }^{a}$, while, ocensionally, tracts of cylindrical epithelium were found ruming in all dircetions through the fibrous stroma. 'These chains were quite long. sometimes bramched, mod usmally not more then two or three rells in width, presenting somewhat the appearance of coil gland ducts. Only a fow of them terminuted in cests, ind no ronnextion could be traced between them and either the sweat apparatus or the blood-vessels.

It is very probable that this growtl, which elinically did not resemble any hitherto reported, was simply a mixed tumor, and that the two types of epithelial struetures composing it were in no wise related. The most important evidence in support of the swent-gland theory of histogenesis of these tumors is the resemblance between the epithelial strands, nests and eysts, and the

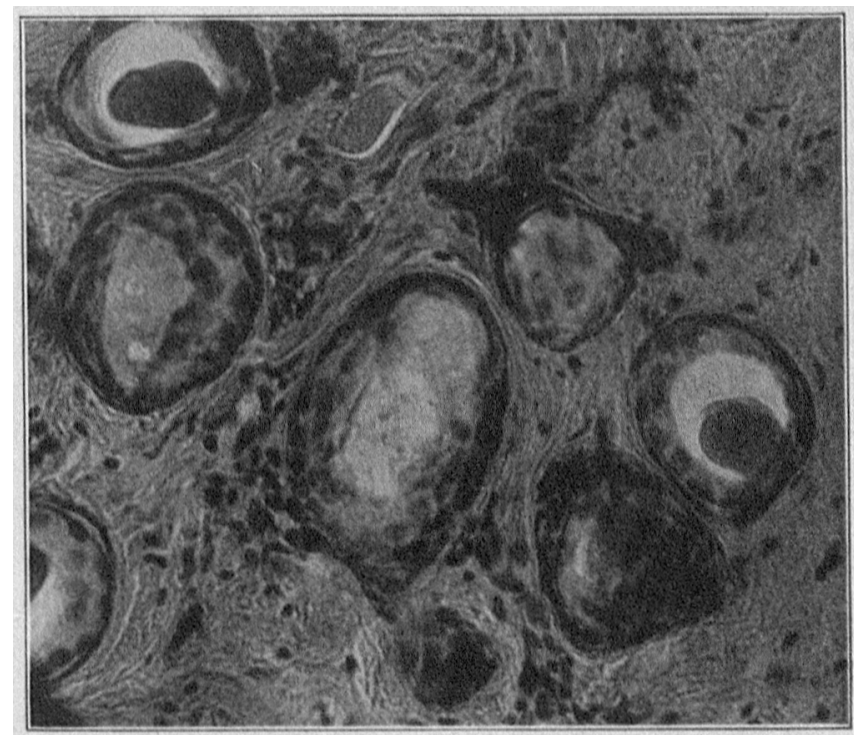

Fig. 4.-Sylingocystadenomn. showing fnitened oplthellni lining

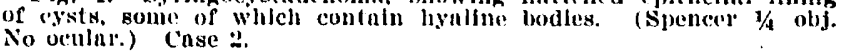

tubules of normal coil-glands. There is a manifest similarity between the nardow, often wavy or twisting strands of epithelium commerterl with the cysts and the normal tubules of roil-glands, but most significant and comvineing is the presence in mnny of the eysts and tubular strands of the double row of epithalial eclls. the outer row flat and the immer row enbieal, presisely the arrangement so characteristic of the collular lining of the sudoripmous tubules. While this armugement is not in all plames applarent in ennecpuence of pressure of the contents of the rest, proliferntion of cells, and ofher olvioms causes, it ean bo recosnizod in so many places that it ammot lo doubted that it is a characteristic histolonio foature of this class of tumors.

'The ilecision of the guestion as to whether the tumor springs from previonsly normal sweateduets or trom comgenital or acepuiped rlofects of the sweat-glands is more poblematic. Comsiderable woight is to be given Jörokis"s aremonent, who made the first thorougly study of the histogemesis of lymplangioma tuberosum multi-

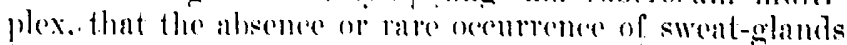
in the alea of the tumor, in emtrast to the presence of

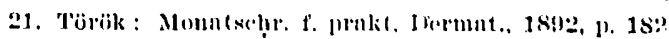


these appendages in the normal skin, is inclicative of the transformation of preexisting sweat tubules into tumor elements. 'Jhe findings in the case leere reported tend to confirm this theory, and the fact that epritholial stands, similar to those found in the tumor areas, may and do occur in apparenty normal regious is additional evidence in support of this hypothesis.

In favor of the congenital theory is the oceurrence in so many instances of the affection in early lil'e, and especially its oceurrence in several members of the sime family. Schidachi 22 has produced similar cysts, even with epithelial stmonds, by oceluding the sweat-ducts, and Unna ${ }^{23}$ describes a budding epithelial process in spiroadenomata occurring in the neighborhood of variess of the leg apparently similar to the proliferative clianges seen in some cases of Jymphangioma tuberosum multiplex. Pick ${ }^{24}$ objects to regarding these growths as true

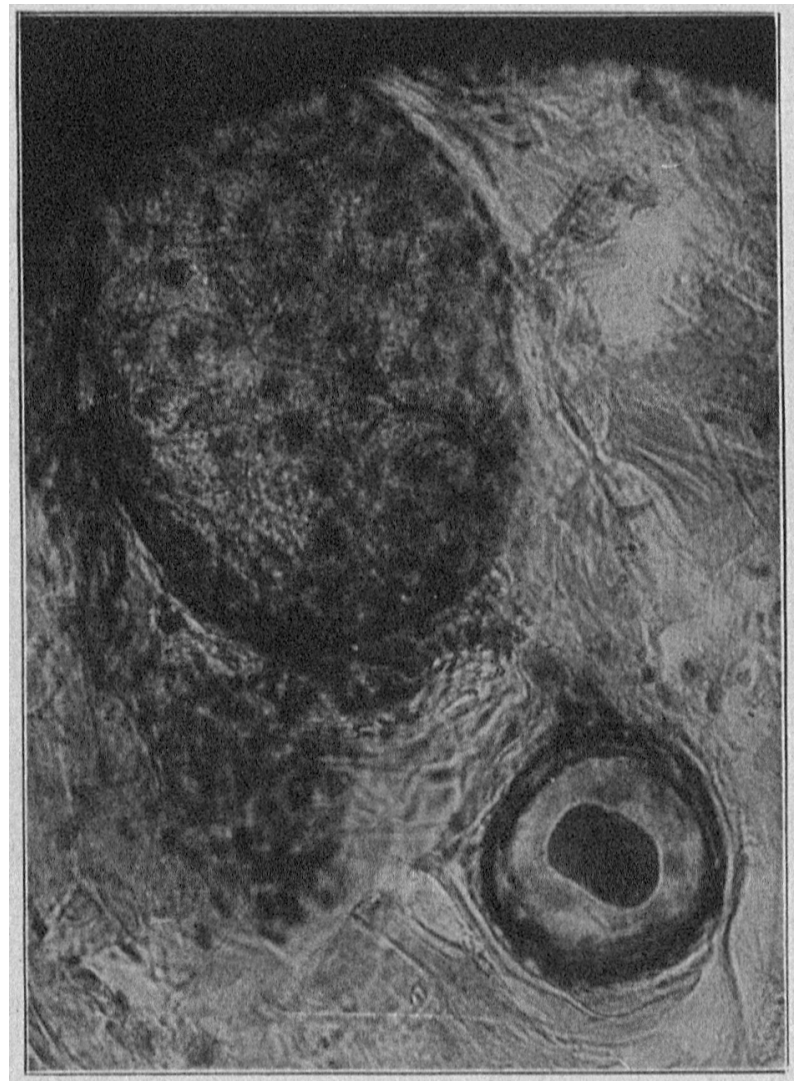

Fig. 5.-Svrlngocystadenomn. showing eplthelinl atrand nptenr.

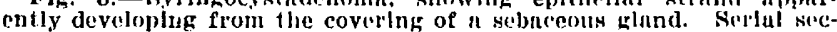
tlons showed that there was no connection between the wo subslances. (Spencer $1 / 0$ obj. No ocular.) Case 2.

alenomata, the question being whether there is anything in the nature of a true secrotion. If the hyaline or colloid material in the eysts is merely the result of eellular degeneration the propricty of such numes as cystoma and cystadenoma would be questionable, but Stockmann ${ }^{14}$ has apparently shown that, in some instances, the cysts and tubules contrin gemuine socetion, and the fuct that some of the tumors in our case incrensed in size following the administrution of pilocappin would tend to confirm Stoekmam's fimlings. Strictly speakjug, these growths are benign cystic epitheliomata, although that name had best be reserved for the J3rookeFordyce type of neoplasm, and a more approprinte and descriptive one ailopted f'or tumors of this group. The

22. Schfduchi: Arcl. f. J)ernut. 11. Sypli.. 19)7. 1. 3.

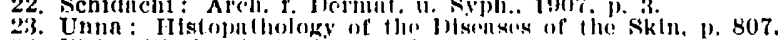

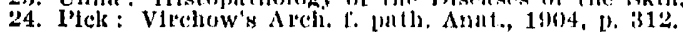

designation "syringorsindenomn," snggested by 'Jürök, appears to us to be very nppropriate, being expressive and at the same time concise.

The extremely interesting and very extrnordinary cxample of sweat-gland tuinor recently reported liy Orunsby, ${ }^{25}$ is exceedingly difficult to classily properly. So far as we can find, no similar case has ever before been described. Jngman's ${ }^{20}$ suggestion that the sudden and widespread multiplication of certain types of cells might be due to a specific chemical acent acting as a stimulant, as claimed by Starling in formulating his now generally accepted hormone theory, is of great interest, even though Webster's ${ }^{27}$ carcefil and cxhanstive analyses proved fruitless in this instance.

\section{CONCLUSIONS}

Lymphangioma tuberosum mitiplex or, better, syringocystadenoma, is a non-malignant, cystic neoplasm derived from misplaced embryonal coil-gland elements. The cells still retain their swent-secreting function, hence the tumors are true adenomata.

Although these growths are, in renlity, benign crstic epitheliomata, they distinctly differ, both clinically und microscopically, from the acanthoma adomoinles cystirum originally described by Brooke and by Fordyce. If the term "multiple benign cystic epitheliomn" is to be retained, its use should be confined strictly to tumors of the Brooke-Fordyce group, and a more fitting nnd proper designation, as syringocystadenoma, adopted for the neoplasms which have so long heen indexed under the euphonions but misleading appellation of "Iymplanngioma tubcrosum multiplex."

We desire to express on very grent jndebtedness to Professor William IT. Weleh, of Jolms Hopkins TTniversity, for his opinion regneding the syringocystadenoma sections. Much of the included summary is quoted almost directly from his personal communication to us, and we feel that his knowledge and discussion liave gone far toward clearing up the puzzling subject in question.

\section{TREATMENT OF NON-UNION OF FRACTUIRES *}

\section{J. SHELTON TIORSLEY, M.D.} HICHNOND, VA.

A fracture which has been apparently. properly reduced and treated nccording to the orthodox manner is supposed to go on to successful healing. Fortumately. this is usually the case. Occasionally, however, without any apparent canse, union fails to occur, and such an outcome is both distressing to the patient and cmbrirassing to the surgeon. Thuoretienlly, bone should repair perfectly, as it belongs to the comnective tissue group of tissues that are simple in construction and consequently easy of fepair. We know that simple tissues reprit readily, wherens the more complicated tissues, such as brain and epithelinl and glandular struetures, either do not repair at all, or else rery imperfectly alter a nolonged time. 'This is a simple, common-sense, biologric law that we would maturally expect. The exception in the case of hone is more apparent than real. The genera] connective tissue frame-work of the bone is built w1 even where no union occurs. The fault lies in the failwre of the tissues to deposit lime salts, as the mincinal

25. Ormsby: Tour, Cutan. Dis, 1010, p. 433.

- Rend before Itchmond lendemy of jedletne and surgery, Nov. 